\title{
Penerapan Model Discovery Learning untuk Meningkatkan Hasil Belajar Matematika Materi Operasi Hitung Bilangan Bulat Siswa Kelas V
}

\author{
Diterima: \\ 5 Juni 2021 \\ Revisi: \\ 28 Juli 2021 \\ Terbit: \\ 1 Februari 2022
}

\author{
Muhammad Wildanum Mucholladum \\ SDN Manyaran 4 Kediri \\ Kediri, Indonesia \\ E-mail: wildanum1101@gmail.com
}

\begin{abstract}
Abstrak - Tujuan penelitian ini adalah meningkatkan penguasaan perkalian pada siswa dan meningkatkan proses pembelajaran mata pelajaran Matematika serta meningkatkan hasil pembelajaran siswa. Penelitian ini menggunakan penelitian tindakan (action research) sebanyak tiga putaran. Setiap putaran terdiri dari empat tahap yaitu rancangan, kegiatan dan pengamatan, refleksi dan refisi. Sasaran penelitian ini adalah siswa Kelas V SDN Manyaran 4 Kelas V Tahun Pelajaran 2020/2021 dengan jumlah peserta didik 15 siswa. Data awal yang diperoleh berupa hasil tes formatif dan dilengkapi lembar observasi kegiatan belajar mengajar. Rata-rata hasil belajar siswa sebelumnya adalah kurang dari 55, namun setelah peneliti menerapkan model discovery learning sebagai sarana mamahami operasi hitung bilangan bulat didapatkan hasil yang memuaskan yaitu rata-rata hasil belajar siswa pada siklus I meningkat menjadi 70 dan pada siklus II meningkat menjadi 84 . Hasil ini menunjukkan bahwa penelitian yang dilakukan oleh peneliti telah berhasil meningkatkan hasil belajar siswa. Berdasarkan penelitian ini dapat disarankan agar guru yang kondisi lingkungan hampir sama dengan yang dilakukan oleh peneliti sebaiknya menggunakan metode pembelajaran discovery learning.
\end{abstract}

Kata Kunci- discovery learning, hasil belajar, matematika

\begin{abstract}
The purpose of this research is to increase students' mastery of multiplication and improve the learning process of Mathematics subjects and improve student learning outcomes. This study uses three rounds of action research. Each round consists of four stages, namely design, activity and observation, reflection and revision. The target of this research is the fifth grade students of SDN Manyaran 4 grade V for the 2020/2021 academic year with a total of 15 students. Initial data obtained in the form of formative test results and equipped with observation sheets of teaching and learning activities. The previous average student learning outcomes were less than 55, but after the researchers applied the discovery learning model as a means of understanding integer arithmetic operations, satisfactory results were obtained, namely the average student learning outcomes in the first cycle increased to 70 and in the second cycle increased to 84 These results indicate that the research conducted by the researcher has succeeded in improving student learning outcomes. Based on this research, it can be suggested that teachers whose environmental conditions are almost the same as those carried out by researchers should use the discovery learning method.
\end{abstract}

Keywords - discovery learning, learning outcomes, mathematics 


\section{PENDAHULUAN}

Proses pembelajaran Matematika mutlak tercantum dalam Kurikulum 2013 (Akbar, 2013). Proses mempelajari Matematika dengan benar akan melatih siswa menggunakan prinsip-prinsip logika dalam mengevaluasi apakah informasi yang diperoleh itu benar atau salah. Proses ini akan mengasah ketajaman siswa dalam berpikir kritis dan menggunakan logika. Belajar itu pada hakekatnya merupakan suatu proses yang bermakna. Belajar matematika itu harus merupakan belajar bermakna dan pengertian. Matematika merupakan dasar teknologi yang merupakan tulang punggung pembangunan. Selain itu, Matematika mampu mengembangkan sikap ilmiah yang membentuk insan Indonesia berkepribadian luhur (Halimah 2014). Nilai-nilai pendidikan tercermin pada sikap ilmiah yang mulai muncul saat pembelajaran yang ditandai dengan munculnya rasa keingintahuan.

Pembelajaran Matematika di SD merupakan bidang studi yang sebenarnya menarik untuk dipelajari karena karakteristiknya yang berbeda dengan bidang studi yang lain, walaupun ada sebagian siswa yang menganggapnya sebagai muatan pelajaran yang rumit dan ditakuti siswa (Sudin 2014). Oleh sebab itu, guru sebagai pembelajar dan pendidik memiliki peran yang dominan untuk meningkatkan hasil belajar siswa sekaligus meluruskan persepsi negatif siswa terhadap muatanpelajaran Matematika tersebut. Guru harus dapat menanamkan konsep Matematika dengan tepat dan harus pandai-pandai memilih metode pembelajaran yang sesuai dengan karakteristik muatan pelajaran Matematika dan karakteristik siswa (Ramadhani et al. 2020). Berdasarkan kegiatan belajar mengajar yang pernah di alami peneliti dalam bidang studi Matematika yakni pada materi operasi hitung bilangan bulat, maka terkumpul data bahwa siswa merasa jenuh saat guru menjelaskan materi tentang operasi hitung bilangan bulat pada muatan pelajaran Matematika di kelas V. Kurangnya metode pembelajaran yang disiapkan untuk mendukung penjelasan guru. Sulitnya siswa dalam memahami materi yang disampaikan guru (Qamaria and others 2020). Selain itu, hasil belajar siswa kelas V di SDN Manyaran 4 Kecamatan Banyakan Kabupaten Kediri Tahun Pelajaran 2020/2021 dari 15 siswa yang berhasil mencapai Kriteria Ketuntasan Minimal (KKM) 75 hanya 5 siswa.

Terkait masalah tersebut peneliti perlu melaksanakan penelitian tindakan kelas dan mengadakan beberapa perbaikan dalam pembelajaran Matematika, sehingga nantinya nilai siswa dapat mencapai KKM yang di targetkan. Berdasarkan pertimbangan di atas, peneliti menyusun sebuah penelitian tindakan kelas dengan judul "Penerapan model pembelajaran Discoveri Learning untuk meningkatkan hasil belajar matematika materi Operasi Hitung Bilangan Kelas V". Berdasarkan judul tersebut dirumuskan tujuan penelitian tindakan ini adalah 
PTK, Vol.2 No.2 2022

ISSN: 2747-1977 (Print) / 2747-1969 (Online)

DOI: https://doi.org/10.53624/ptk.v2i2.48

untuk menjelaskan peningkatan hasil belajar matematika operasi hitung bilangan bulat pada siswa kelas V SDN Manyaran 4 Kecamatan Banyakan Kabupaten Kediri.

\section{METODE}

\section{A. Pendekatan Penelitian}

Penelitian Tindakan (Action Research) merupakan pendekatan yang semakin banyak dan diperlukan dan diandalkan dalam rangka meningkatkan mutu pendidikan di Indonesia, terutama dalam peningkatan mutu, relevansi dan efisiensi pengelolaan pendidikan. Hal ini terjadi karena Penelitian Tindakan dalam konteks pendidikan banyak mengkaji interaksi (proses belajarmengajar) yang terjadi dalam kelas di sekolah- sekolah (Arikunto, 2010).

Perbaikan proses belajar- mengajar di dalam kelas dan pengelolaan sekolah dipandang sebagai pusat tumpuan peningkatan mutu hasil belajar siswa dan efisiensi pendidikan. Jika kita bermaksud memahami cara kerja sekolah dan hendak mengubah atau meningkatkan peranannya, maka yang sangat penting dimengerti adalah apa yang terjadi di dalam kelas. Sebagian besar dari wujud nyata kegiatan pendidikan di sekolah dapat diamati di dalam kelas.

Sedangkan penelitian tindakan (Action Research) memiliki lingkup yang lebih luas, karena tidak saja mengkaji dan melakukan tindakan dalam lingkup kelas, tetapi dapat mencakup satu sekolah bahkan dapat beberapa sekolah.

\section{B. Subjek Penelitian}

Subjek yang diteliti pada penelitian ini adalah siswa kelas V semester genap tahun ajaran 2020/2021 di SDN Manyaran 4 Kecamatan Banyakan Kabupaten Kediri dengan jumlah siswa sebanyak 15 siswa.

\section{Waktu Pelaksanaan}

Waktu penelitian ini dilaksanakan mulai tanggal 17 Oktober 2020 sampai tanggal 24 Oktober 2020 semester ganjil tahun pelajaran 2020/2021.

D. Data dan Instrumen Penelitian

Data pada penelitian ini adalah data berupa ketercapaian pembelajaran jarak jauh menggunakan metode discovery of learning menggunakan instrument lembar observasi dan data hasil belajar siswa pada materi menganalisis siklus air. Data ketercapaian pembelajaran merupakan data kualitatif berupa catatan-catatan guru terhadap kekuatan dan kelemahan proses pembelajaran, sedangkan data hasil belajar merupakan data kuantitatif yang akan diambil sebanyak empat kali selama dua siklus (dua kali pada masing-masing siklus). Data hasil belajar 
diambil dari soal evaluasi, soal ini dikembangkan menjadi lima soal pilihan ganda dan tujuh soal jawaban singkat, kriteria ketuntasan minimal (KKM) pengerjaan soal ini adalah mendapatkan skor $75 \%$.

\section{E. Teknik Analisis Data}

Analisis data pada penelitian ini menggunakan teknik kualitatif dan kuantitatif. Untuk data kualitatif adalah data ketercapaian pembelajaran, yaitu data kekuatan dan kelemahan pembelajaran di bahas, direfleksikan, dan di rumuskan simpulannya. Untuk data deskriptif kuantitatif adalah data angka hasil belajar siswa, dibandingkan dengan KKM, dianalisis, dan dimaknai secara deskriptif.

\section{HASIL DAN PEMBAHASAN}

\section{A. Hasil Ketercapaian Pembelajaran}

Dalam melaksanakan penelitian yang direncanakan terdiri dari dua siklus dengan waktu tanggal 17 Oktober 2020 dan 24 Oktober 2020.

Langkah-langkah yang dilakukan selama penelitian adalah sebagai berikut:

1. SIKLUS I

a. Hasil Pengamatan Kelas

Siklus I dilaksanakan pada tanggal 17 Oktober 2020 di Kelas VI. Hasil pengamatan kelas di peroleh dari pembelajaran secara daring dengan gambaran sebagai berikut:

1) Hasil belajar siswa belum menunjukkan sebagaimana layaknya diskusi, masih malu bertanya saat pembelajaran melalui zoom meeting

2) Siswa aktif mengerjakan soal sendiri-sendiri.

3) Masih ada siswa atau beberapa siswa yang merasa kurang waktu untuk mengerjakan soal-soal.

4) Untuk pengamatan keseluruhan terhadap kegiatan belajar sudah berlangsung baik, walaupun masih ada kekurangan yang ditampilkan siswa, yang belum mengikuti pembelajaran daring melalui zoom secara maksimal. Hal ini disebabkan dari faktor yang rendah kemampuannya dalam menguasai materi pelajaran, Sinyal kurang putus-putus. Monitoring yang dilaksanakan kepada siswa melalui pengamatan dengan metode tanya jawab dan pengunaan model Discovery Learning PPT, siswa merasa dibantu dalam berpikir untuk menyelesaikan soal-soal.

Ditemukan jawaban dari beberapa siswa yang menyatakan bahwa bersaing untuk kreatif, berpikir kritis, percaya diri dalam menyalurkan kemampuannya kepada teman. 
PTK, Vol.2 No.2 2022

ISSN: 2747-1977 (Print) / 2747-1969 (Online)

DOI: https://doi.org/10.53624/ptk.v2i2.48

Adapun hasil penelitian melalui pengamatan kepada siswa diperoleh hasil-hasil sebagai berikut:

1) Siswa dalam menyelesaikan masalah secara mandiri belum berjalan dengan baik.

2) Siswa masih kurang aktif dalam membahas soal dan masih adadominasi oleh teman yang pandai saja.

3) Pemahaman materi secara keseluruhan masih belum maksimal.

Tabel 1. Tabel Tes Nilai Akhir

\begin{tabular}{lll}
\hline PRESTASI SISWA & SIKLUS 1 \\
\cline { 2 - 3 } & Jumlah siswa & Prosentase \\
\hline Nilai $<75$ & 3 & $25 \%$ \\
Nilai $>75$ & 9 & $75 \%$ \\
\hline Tuntas belajar & 3 & $25 \%$ \\
Tidak tuntas belajar & 9 & $75 \%$ \\
\hline Jumlah & 12 & $100 \%$ \\
\hline Nilai rata-rata & 70 & $48 \%$ \\
\hline Taraf Seraf & \multicolumn{2}{l}{} \\
\hline Ketuntasan & Belum tuntas belajar \\
secara klasikal & & \\
\hline
\end{tabular}

Hasil tes siklus I sebagaimana tabel 1 di atas menujukkan bahwa sebanyak $25 \%$ siswa yang telah memperoleh nilai $<75$ dan sebanyak $75 \%$ siswa yang memperoleh nilai di bawah 75 . Berdasarkan uraian di atas dievaluasi langkah-langkah yang telah diprogramkan dan dilaksanakan pada siklus I, belum mampu mencapai tujuan yang diharapkan oleh peneliti, maka peneliti dipakai, sehingga ditemukan variasi yang tepat untuk mencapai tujuan. Kemudian peneliti melanjutkan pada program siklus II yang direncanakan dengan berbagai revisi yaitu peneliti memantau jalannya belajar diskusis kelas dalam masing-masing kelompok.

b. Refleksi Siklus I

Berdasarkan data yang diperoleh dalam penelitian ini, akan dipahami beberapa hal yaitu pembelajaran yang dilaksanakan pada siklus I belum berhasil. Hal tersebut diketahui berdasarkan data yang dihimpun dalam penelitian ini.

1) Hasil pengamatan pada saat guru melakukan pembelajaran

Pada pengamatan siswa pada saat KBM berlangsung, belum memadai yang diharapkan peneliti dengan mewujudkan keaktifan dalam mengikuti belajar. Sedangkan observasi guru sudah memadai pada kriteria struktur dan strategi pengajaran. 
2) Hasil tes

Pada akhir siklus I masih ada dari $75 \%$ siswa yang mengalami kesulitan dalam mengerjakan soal. Hal ini mungkin disebabkan oleh kurangnya pemahaman siswa terhadap soal, kurangnya latihan, model Discovery Learning yang kurang menarik, terbatasnya buku pelajaran penunjang, atau kondisi siswa pada saat mengikuti pelajaran kurang menujukkan adanya rasa keseriusan atau motivasi serta belum berjalannya kerjasama siswa dalam mengerjakan tugas diskusi. Siswa tersebut enggan bertanya kepada guru maupun kepada teman diskusinya tentang cara-cara menyelesaikan soal untuk memahami operasi hitung bilangan bulat.

Kenaikan tersebut belum sesuai dengan tujuan yang diharapkan. Nilai yang diperoleh pada siklus I terendah 60 , nilai tertinggi 80 , nilai rata-rata 70 dan daya serap mencapai $48 \%$. Hal tersebut berarti belum mencapai ketuntasan belajar secara klasikal.

\section{SIKLUS II}

Siklus II dilaksanakan pada tanggal 24 Oktober 2020 di Kelas 5 SDN Manyaran 4. Hasil penelitian pada siklus II dapat dipaparkan sebagai berikut.

a. Hasil Pengamatan

Dalam pengamatan kelas yang dilaksanakan kepada beberapa siswa melalui pembelajaran diskusi diperoleh hasil sebagai berikut.

1) Pembelajaran dilaksanakan dengan cukup baik.

2) Ada peningkatan keaktifan belajar dibandingkan pertemuan siklus II diwujudkan dengan saling tukar pendapat dalam menyelesaikan soal-soal.

3) Siswa memperlihatkan kemampuan terhadap pemahaman materi dan disalurkan kepada temannya yang belum memahami materi.

4) Pengamatan secara keseluruhan terhadap KBM, masing-masing dapat menyelesaikan soal-soal dengan baik dan sistematis sesuai dengan yang diharapkan peneliti

Dengan demikian siswa tumbuh percaya diri dalam menghadapi masalah terlihat pada tes akhir siklus II. Dari pengamatan kelas di peroleh pula gambaran sebagai berikut.

1) Keaktifan belajar siswa sudah menunjukkan sebagaimana layaknya kegiatan diskusi dan tanya jawab dan terlihat lebih hidup pembelajarannya.

2) Siswa aktif dalam mengerjakan soal secara bersama atas dasar kemampuan sendirisendiri dan kerjasama untuk membahas soal. 
PTK, Vol.2 No.2 2022

ISSN: 2747-1977 (Print) / 2747-1969 (Online)

DOI: https://doi.org/10.53624/ptk.v2i2.48

3) Untuk pengamatan keseluruhan terhadap kegiatan belajar sudah berlangsung baik, walaupun masih ada kendala sinyal sehingga suara saat zoom metting terkadang kurang jelas.

Adapun hasil observasi kepada siswa Kelas V siklus II diperoleh gambaran sebagai berikut.

1) Siswa senang menggunakan metode tanya jawab.

2) Siswa sangat aktif bertanya kepada guru saat KBM melalui zoom metting maupun WA, jika mengalami kesulitan dalam mengerjakan soal-soal.

3) Siswa selalu belajar teratur supaya mendapat nilai baik.

4) Siswa berusaha memperbaiki kesalahan-kesalahan yang merasa dirinya kurang mampu dalam pemahaman materi.

Tabel 2. Tes Nilai Akhir

\begin{tabular}{lll}
\hline PRESTASI SISWA & SIKLUS 2 & \\
\cline { 2 - 3 } & $\begin{array}{l}\text { Jumlah } \\
\text { siswa }\end{array}$ & Prosentase \\
\hline Nilai $<75$ & 11 & $92 \%$ \\
Nilai $>75$ & 1 & $8 \%$ \\
\hline Tuntas belajar & 11 & $92 \%$ \\
Tidak tuntas belajar & 1 & $8 \%$ \\
\hline Jumlah & 12 & $100 \%$ \\
\hline Nilai rata-rata & 84,16 & \\
\hline Taraf Seraf & $90 \%$ & \\
\hline Ketuntasan secara & Tuntas belajar & \\
klasikal & & \\
\hline
\end{tabular}

Data tes akhir siklus II bahwa nilai rata-rata yaitu 84 dan daya serap $90 \%$ merupakan tes akhir siklus II. Pelaksanaan siklus II merupakan pelaksanaan ulang dari siklus I yang direncanakan berdasarkan refleksi-refleksi. Hasil tes akhir siklus II dapat dilihat pada lampiran kegiatan perbaikan ini. Data yang diperoleh memberlihatkan hasil bahwa nilai ratarata kelas siklus I mencapai 70 dan pada akhir siklus II rata-rata kelas naik menjadi

84. Sampai pada akhir siklus II, banyaknya siswa yang mendapat nilai 75 ke atas sebanyak 11 siswa dari 15 siswa atau $92 \%$. Hal ini berarti bahwa ketuntasan belajar klasikal sudah ada peningkatan yang banyak yaitu dari $25 \%$ menjadi $92 \%$, maka pada siklus II materi operasi hitung bilangan bulat di Kelas V SDN Manyaran 4 mencapai daya serap secara klasikal rata-rata kelas mencapai $90 \%$.

Siswa yang masih memperoleh nilai di bawah 75 sebanyak 1 anak. Dengan kata lain model Discovery Learning dapat meningkatkan hasil belajar dalam KBM pada materi 
operasi hitung bilangan bulat siswa SDN Manyaran 4 Kecamatan Banyakan Kabupaten Kediri.

b. Refleksi Siklus II

Atas dasar data hasil pengamatan siswa pada saat KBM berlangsung, pembelajaran dikatakan sangat baik dan kondusif sesuai yang diharapkan peneliti dengan mewujudkan keaktifan dalam mengikuti belajar. Analisis data kualitatif terhadap mutu pembelajaran, siswa antuasias ingin mengetahui konsep matematika melalui model Discovery Learning. Refleksi dari data kuantitatif mengenai jumlah siswa yang mengikuti pembelajaran matematika dalam pembelajaran dengan model Discovery Learning yang dilaksanakan siklus II sebanyak 100\% hadir mengikutinya.

Keberhasilan tidakan kelas dengan model Discovery Learning di Kelas V mencapai $90 \%$ tersebut dianggap tuntas belajar dan meningkatkan prestasi belajar siswa, hal tersebut sesuai dengan fungsi dan kebaikkan model Discovery Learning itu sendiri. Model Discovery Learning yang digunakan dalam pembelajaran menjadi lebih efektif dan efisien. Keisitimewaan model Discovery Learning adalah memudahkan guru dalam mengawasi murid-murid dalam melakukan kegiatan, membina semangat kerjasama yang sehat, secara psikologis, metode ini membangkitkan semangat bersaing yang sehat di antara kelompokkelompok kecil, pokok pikiran yang dibahas yang berupa tugas guru dapat diselesaikan lebih cepat dan hasilnya lebih matang dan dipertanggungjawabkan. Model discovery learning yang dilaksanakan dalam tindakan kelas, telah mampu meningkatkan prestasi belajar pada materi operasi hitung bilangan bulat di Kelas 5 SDN Manyaran 4 Kecamatan Banyakan Kabupaten Kediri Tahun Pelajaran 2020/2021 hasil ini senada dengan hasil pengelitian sebelumnya yang menyimpulkan bahwa menggunakan model pembelajaran discovery elarning dapat meningkatkan hasil belajar matematika siswa (Rahmawati 2020).

\section{KESIMPULAN}

Berdasarkan hasil dan pembahasan di atas, dapat disimpulkan bahwa pembelajaran matematika dengan menggunakan model discovery learning dapat meningkatkan prestasi belajar pada materi operasi hitung bilangan bulat di Kelas 5 SDN Manyaran 4 Kecamatan Banyakan Kabupaten Kediri Tahun Pelajaran 2020/2021. Tugas utama seorang guru bukan hanya mendidik, mengajar, dan melatih siswa. Akan tetapi yang lebih penting bagi guru dapat menumbuhkan minat belajar siswa yang menyenangkan melalui kegiatan diskusi kelas, sehingga dapat melatih keberanian. Pembelajaran matematika di SDN Manyaran 4 seharusnya dilakukan dengan berbagai pendekatan. Pendekatan dan metode yang tepat membuat siswa lebih 
PTK, Vol.2 No.2 2022

ISSN: 2747-1977 (Print) / 2747-1969 (Online)

DOI: https://doi.org/10.53624/ptk.v2i2.48

mudah menguasai pembelajaran dengan lebih cepat. Pembelajaran dengan menemuakan sendiri permasalahan yang muncul membuat siswa akan selalu terkenang dalam pembelajaran matematika. Peran guru sangat penting untuk terciptanya pembelajaran yang bermakna dan mengena pada siswa. Guru harus menguasai teori-teori pembelajaran untuk menggalai potensi siswa khususnya mata pelajaran Matematika. Melalui metode discoveri of learning ini mampu meningkatkan prestasi belajar Matematika.

\section{DAFTAR PUSTAKA}

Akbar, Sa'dun. 2013. Instrumen Perangkat Pembelajaran. Bandung: Rosdakarya. Arikunto, Suharsmi. 2000. Dasar-dasar Evaluasi Pendidkan. Bina Aksara.

Halimah, Siti. 2014. "Implementasi Kurikulum 2013 Dalam Pembelajaran Matematika."

Qamaria, Rezki Suci and others. 2020. "The Effectiveness of Google Classroom as English Learning Assistance." Kontribusi: Jurnal Penelitian Dan Pengabdian Kepada Masyarakat 1(1):47-53.

Rahmawati, Elly. 2020. "Upaya Peningkatan Hasil Belajar Matematika Siswa Kelas XI IPA SMA Negeri 1 Kediri Melalui Model Pembelajaran Discovery Learning." PTK: Jurnal Tindakan Kelas 1(1):48-70.

Ramadhani, Rahmi, Masrul Masrul, Dicky Nofriansyah, Mustofa Abi Hamid, I. Ketut Sudarsana, Sahri Sahri, Janner Simarmata, Meilani Safitri, and Suhelayanti Suhelayanti. 2020. Belajar Dan Pembelajaran: Konsep Dan Pengembangan. Yayasan Kita Menulis.

Sudin, Ali. 2014. Kurikulum Dan Pembelajaran. UPI Press. 